\title{
Endocrinological Changes before and after Removal of The Granulosa Theca Cell Tumor (GTCT) Affected Ovary in 6 Mares
}

\author{
MD. Shafiqul HOQUE ${ }^{1,2)}$, Hiroyuki SENBA ${ }^{3)}$, Nobuo TSUNODA ${ }^{4)}$, Refaat Ibrahim DERAR ${ }^{1,5)}$, Gen WATANABE ${ }^{6)}$, \\ Kazuyoshi TAYA ${ }^{6)}$, Takeshi OSAWA ${ }^{1)}$ and Yoh-Ichi MIYAKE ${ }^{1)}$ \\ ${ }^{1)}$ Laboratory of Theriogenology, Department of Veterinary Medicine, Faculty of Agriculture, Iwate University, Morioka 020-8550, \\ ${ }^{2)}$ Department of Clinical Veterinary Science, The United Graduate School of Veterinary Sciences, Gifu University, Gifu 501-1193, \\ ${ }^{3}$ NOSAI Hidaka, Clinic Center, Mitsuishi 059-3105, 4) Shadai Stallion Station, Hayakita 059-1432, 5) Department of Theriogenology, \\ Faculty of Veterinary Medicine, Assiut University, Egypt and ${ }^{6)}$ Laboratory of Veterinary Physiology, Department of Veterinary Medicine, \\ Faculty of Agriculture, Tokyo University of Agriculture and Technology, Fuchu 183-8509, Japan
}

(Received 1 November 2002/Accepted 10 April 2003)

ABSTRACT. To clarify the endocrinological characteristics of the mares with granulosa theca cell tumor (GTCT), peripheral plasma samples from the 6 mares affected with GTCT were collected before and after the surgical removal of the affected ovary. Concentrations of testosterone $(\mathrm{T})$, follicle stimulating hormone $(\mathrm{FSH})$, luteinizing hormone $(\mathrm{LH})$, immunoreactive-inhibin (ir-INH), progesterone (P) and estradiol-17 $\beta\left(\mathrm{E}_{2}\right)$ in the plasma samples were measured by radioimmunoassay. Before removal of GTCT in all cases, the concentrations of $\mathrm{T}$ were significantly higher than those of normal mares at the breeding and non-breeding seasons, whereas plasma concentrations of $\mathrm{FSH}, \mathrm{LH}$, ir-INH, $\mathrm{P}$ and $\mathrm{E}_{2}$ were lower. After surgical removal of the affected ovary, the circulatory concentrations of $\mathrm{T}$ was declined, but the concentrations of other hormones were constantly low as compared with those of normal mares. The present study suggests that 1) the source of higher T may be due to the abnormal follicles in ovary of GTCT, 2) in the case of GTCT the elevated level of T is observed due to the lack of aromatase, and 3) the high level of $\mathrm{T}$ is a typical characteristics for GTCT in mares. It is also suggested 4) due to the elevated levels of $\mathrm{T}$ the concentrations of gonadotropins may be suppressed.

KEY WORDS: before and after removal of ovary, endocrinological finding, granulosa theca cell tumor (GTCT), mare.

J. Vet. Med. Sci. 65(8): 887-891, 2003

Granulosa Theca Cell Tumor (GTCT) are the most common ovarian tumor of the mare $[2,4,13,18]$. GTCT occur unilaterally and contralateral ovary is usually small and firm $[2,4,6,7]$. They arises from the sex cord stroma that lines the ovulation fossa $[13,14]$. GTCT are usually benign and composed primary of neoplastic granulosa cells but may also contain abnormal theca cells [18, 21, 22, 24]. GTCTs are usually steroid producing tumors, often associated with behavioral changes and poor reproductive performance. However, the surgical removal of the affected ovary is effective for the return of estrus. Therefore, it is very important to diagnose GTCT as early as possible for improvement of reproduction in mares.

The GTCT have been diagnosed by the ultrasonographic patterns $[16,26]$ and the measurements of sex steroid hormonal levels [19, 23, 24]. The stallion like behavior was associated with circulating testosterone (T) levels over 100 $p \mathrm{~g} / \mathrm{ml}[19,24]$. Endocrinological substances which may be produced by the tumor may be associated with behavioral changes and suppression of the hypothalamic or pituitary axis $[12,18,23]$. Suppression of pituitary gonadotropin output results in inactive condition of the contralateral ovary [1, 15, 16]. However, there are no reports about the source of high levels of T in GTCT affected mares.

In this paper to clarify the endocrinological characteristics of mares having GTCT, and to investigate the source of hormones, $\mathrm{T}$ levels were determined including follicle stimulating hormone (FSH), luteinizing hormone ( $\mathrm{LH})$, irinhibin $(\mathrm{INH})$, progesterone $(\mathrm{P})$ and estradiol-17 $\beta\left(\mathrm{E}_{2}\right)$ before and after removal of the affected ovaries.

\section{MATERIALS AND METHODS}

Five mares of Thoroughbred and one mare of heavy breed were used in the present study. Diagnosis of GTCT was based on history, rectal palpation, transrectal ultrasound echographic image of ovaries and histopathological investigation. Rectal palpation revealed a large affected ovary with many follicular development and the unaffectd contralateral ovary was usually small and inactive. On ultrasonographic scaning, multilobular "honeycomb" appearance was present. The histopathological diagnosis was done about the affected ovary after removal as shown in previous paper [11].

The size and weight of the affected ovary in 6 mares were given as follows; 13.0-9.7-6.5 cm (length — depth-width) and $530 \mathrm{~g}$ in case $1,16.5-14.4-9.5 \mathrm{~cm}$ and $1,560 \mathrm{~g}$ in case 2 , $18.0-13.5-11.0 \mathrm{~cm}$ and $2,000 \mathrm{~g}$ in case $3,13.5-10.0-8.0 \mathrm{~cm}$ and $820 \mathrm{~g}$ in case 4 and $9.0-7.0-6.0 \mathrm{~cm}$ and $260 \mathrm{~g}$ in case 5 and $9.2-7.8-6.0 \mathrm{~cm}$ and $320 \mathrm{~g}$ in case No. 6. But the contralateral ovary was small and inactive in all cases.

Before and after removal of the affected ovary from these 6 mares, peripheral plasma samples were collected 2 days and $1 \mathrm{hr}$ before operation and just before operation. After operation peripheral plasma samples were collected at 1, 2, 4, 6, 12 and $24 \mathrm{hr}$ and 2, 3 and 7 days and were frozen under $-20^{\circ} \mathrm{C}$ until the hormonal assay. As control, plasma samples from 18 Thoroughbred mares during the non- 
Table 1. Concentrations of peripheral hormones before removal of GTCT in 6 mares

\begin{tabular}{lcccccc}
\hline Case & $\begin{array}{c}\mathrm{T} \\
(\mathrm{pg} / \mathrm{m} l)\end{array}$ & $\begin{array}{c}\mathrm{FSH} \\
(\mathrm{ng} / \mathrm{m} l)\end{array}$ & $\begin{array}{c}\mathrm{LH} \\
(\mathrm{ng} / \mathrm{m} l)\end{array}$ & $\begin{array}{c}\text { ir- } \mathrm{INH} \\
(\mathrm{pg} / \mathrm{m} l)\end{array}$ & $\begin{array}{c}\mathrm{P} \\
(\mathrm{ng} / \mathrm{m} l)\end{array}$ & $\begin{array}{c}\mathrm{E}_{2} \\
(\mathrm{pg} / \mathrm{m} l)\end{array}$ \\
\hline Case 1 & $224.01 \pm 8.06$ & $0.38 \pm 0.04$ & $0.17 \pm 0.03$ & $102.33 \pm 27.91$ & $0.51 \pm 0.06$ & $0.55 \pm 0.31$ \\
Case 2 & $162.97 \pm 12.62$ & $0.21 \pm 0.03$ & $0.14 \pm 0.03$ & $186.22 \pm 46.29$ & $0.86 \pm 0.18$ & $5.27 \pm 0.39$ \\
Case 3 & $488.42 \pm 3.73$ & $0.13 \pm 0.01$ & $0.14 \pm 0.08$ & $255.89 \pm 63.94$ & $0.28 \pm 0.09$ & $1.58 \pm 0.45$ \\
Case 4 & $217.09 \pm 35.79$ & $1.21 \pm 0.11$ & $0.12 \pm 0.01$ & $157.37 \pm 20.82$ & $0.19 \pm 0.05$ & $0.72 \pm 0.14$ \\
Case 5 & $360.74 \pm 1.23$ & $0.41 \pm 0.04$ & $0.13 \pm 0.09$ & $294.42 \pm 22.69$ & $0.11 \pm 0.04$ & $0.71 \pm 0.14$ \\
Case 6 & $132.42 \pm 6.84$ & $0.41 \pm 0.10$ & $0.26 \pm 0.04$ & $156.56 \pm 20.66$ & $0.27 \pm 0.09$ & $0.42 \pm 0.43$ \\
\hline Mean \pm SE & $264.28 \pm 55.09$ & $0.46 \pm 0.16$ & $0.16 \pm 0.02$ & $199.25 \pm 31.36$ & $0.37 \pm 0.11$ & $2.45 \pm 1.07$ \\
\hline
\end{tabular}

breeding season (October to December) and from 9 Thoroughbred mares during the breeding season (April to September) were also collected during in an anestrous condition and stored at same temperature until measurements of hormonal assay. Levels of follicle stimulating hormone (FSH), luteinizing hormone (LH), immunoreactive (ir-) inhibin $(\mathrm{INH})$, progesterone $(\mathrm{P})$, testosterone $(\mathrm{T})$ and estradiol-17 $\beta$ $\left(E_{2}\right)$ in peripheral blood were measured by specific radioimmunoassay (RIA) $[9,25,26]$.

Plasma concentrations of FSH and LH were measured by using a rabbit antiserum against equine FSH (\# AFP2062096) provided by NIDDK, NIH, Betheda, MD, U.S.A.) and LH (\# AFP-240580). Highly purified equine FSH (\# AFP-5022B) and LH (\# AFP-5130A) were used for radioiodination and the reference standard. These materials were kindly provided by Dr. A.F. Parlow (National Hormone and Pituitary Program, Harbor-UCLA Medical Center, CA, U.S.A.). The concentrations of ir-INH in plasma in all cases were determined by using anti-bovine inhibin serum (TDNH-1) and bovine $32 \mathrm{KDa}$ inhibin for radioiodination and the reference standard [9].

The concentrations of $\mathrm{P}, \mathrm{T}$ and $\mathrm{E}_{2}$ in plasma in all cases were determined as described previously [27] by using antisera to P (GDN\#337), T (GDN\#250) and $\mathrm{E}_{2}$ (GDN\#244). The inter and intra assay coefficience of variations of $\mathrm{FSH}$, LH, ir-INH, $\mathrm{P} \mathrm{E}_{2}$ and $\mathrm{T}$ were $8.2 \%$ and $13.2 \% ; 8.8 \%$ and $13.0 \% ; 8.8 \%$ and $14.4 \% ; 3.5 \%$ and $13.4 \% ; 4.8 \%$ and $5.8 \%$ and $6.3 \%$ and $7.2 \%$, respectively.

Most of the data were presented as mean \pm standard error (SE), Significance of difference was compared by Student's unpaired $t$-test. All differences in values of $\mathrm{p}<0.05$ were considered to be significant.

\section{RESULTS}

Average concentrations of T, FSH, LH, ir-INH, $\mathrm{P}$ and $\mathrm{E}_{2}$ before removal of GTCTs are shown in Table 1 and these changes before and after removal of GTCT in all cases are shown in Fig. 1 and Fig. 2.

Before surgical removal of GTCT in 6 mares, the average plasma concentrations of $\mathrm{T}$ were significantly higher $(264.28 \pm 55.09 \mathrm{pg} / \mathrm{m} l)(\mathrm{p}<0.05)$ as compared with those of normal mares at breeding $(25.19 \pm 3.01 \mathrm{pg} / \mathrm{m} l)$ and nonbreeding seasons $(46.94 \pm 9.56 \mathrm{pg} / \mathrm{ml})$. The average concentrations of FSH $(0.46 \pm 0.16 n \mathrm{~g} / \mathrm{ml}), \mathrm{LH}(0.16 \pm 0.02 \mathrm{ng} /$
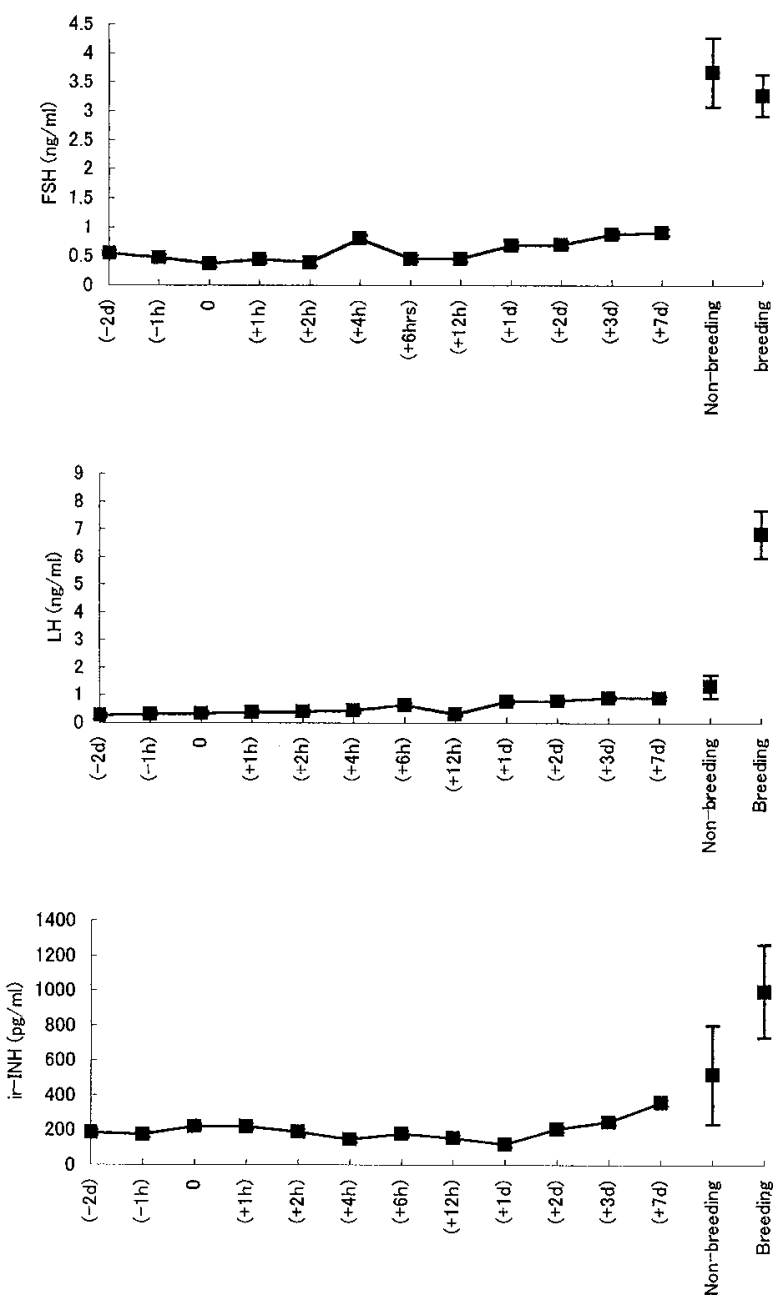

Fig. 1. Changes of plasma concentrations of FSH, LH, and irINH levels before and after removal of the affected ovary as compared with that of the normal mares.

$\mathrm{m} l)$, ir-INH $(199.25 \pm 31.36 \mathrm{pg} / \mathrm{ml}), \mathrm{P}(0.37 \pm 0.11 \mathrm{ng} / \mathrm{ml})$ and $\mathrm{E}_{2}(2.45 \pm 1.07 \mathrm{pg} / \mathrm{m} l)$ were low as compared with those of normal mares at the breeding $(3.3 \pm 0.6 \mathrm{ng} / \mathrm{ml}$ in FSH, $6.81 \pm 2.12 \mathrm{ng} / \mathrm{m} l$ in $\mathrm{LH}, 994.29 \pm 128.67 \mathrm{pg} / \mathrm{m} l$ in ir- $\mathrm{INH}$, $1.93 \pm 0.67 \mathrm{ng} / \mathrm{ml}$ in $\mathrm{P}$ and $8.1 \pm 1.56 \mathrm{pg} / \mathrm{ml}$ in $\left.\mathrm{E}_{2}\right)$ and nonbreeding seasons $(3.6 \pm 0.4 n \mathrm{~g} / \mathrm{m} l$ in FSH, $1.32 \pm 0.43 n \mathrm{~g} / \mathrm{m} l$ 
in $\mathrm{LH}, 516.21 \pm 266.49 \mathrm{pg} / \mathrm{m} l$ in ir-INH, $1.3 \pm 0.14 \mathrm{ng} / \mathrm{m} l$ in $\mathrm{P}$ and $5.08 \pm 0.48 \mathrm{pg} / \mathrm{m} \mathrm{l}$ in $\mathrm{E}_{2}$ ).

After surgical removal of the affected ovary the average concentrations of $\mathrm{T}$ were abruptly declined in all cases
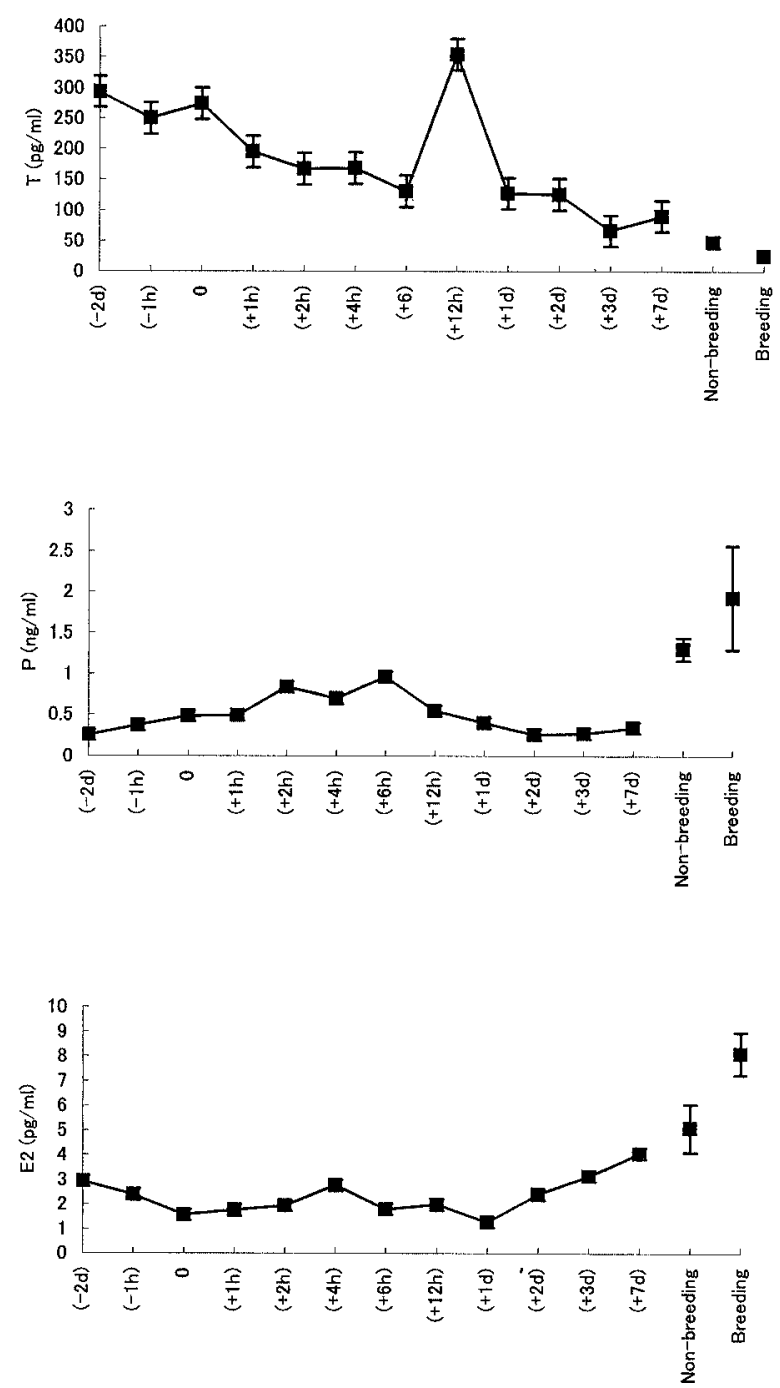

Fig. 2. Changes of plasma concentrations of $\mathrm{T}, \mathrm{P}$ and $\mathrm{E}_{2}$ before and after removal of the affected ovary as compared with that of the normal mares.
$(166.92 \pm 20.74 \mathrm{pg} / \mathrm{m} /)$ (Table 2$)$ and were significantly lower $(\mathrm{p}<0.05)$ as compared with those of before removal of the affected ovaries. The concentrations of FSH $(0.52 \pm$ $0.05 n \mathrm{~g} / \mathrm{ml})$, LH $(0.30 \pm 0.02 n \mathrm{~g} / \mathrm{ml})$, ir-INH $(165.98 \pm$ $35.47 \mathrm{pg} / \mathrm{ml}), \mathrm{P}(0.61 \pm 0.22 \mathrm{ng} / \mathrm{ml})$ and $\mathrm{E}_{2}(1.87 \pm 0.54 \mathrm{pg} /$ $\mathrm{m} l$ ) (Table 2) were constantly low and there were no significant difference as compared with those of before and after removal of the affected ovary. The concentrations of T levels were significantly higher $(\mathrm{p}<0.05)$ as compared with those of breeding and non-breeding seasons in normal mares.

Concentrations of T, FSH, LH, ir-INH, $\mathrm{P}$ and $\mathrm{E}_{2}$ levels in the mares which were operated in breeding seasons (Case Nos. 1, 2, 4 and 5: Group A) were $241.20 \pm 27.98 \mathrm{pg} / \mathrm{ml}$, $0.49 \pm 0.13 \mathrm{ng} / \mathrm{ml}, 0.14 \pm 0.01 \mathrm{ng} / \mathrm{ml}, 185.08 \pm 24.91 \mathrm{pg} / \mathrm{ml}$, $0.41 \pm 0.10 \mathrm{ng} / \mathrm{ml}$ and $1.86 \pm 0.61 \mathrm{pg} / \mathrm{ml}$, respectively (Table 3). The concentrations of T, FSH, LH, ir-INH, P and $\mathrm{E}_{2}$ levels in the mares which were operated in non-breeding seasons (Case Nos. 3 and 6: Group B) were $186.48 \pm 32.43$ $\mathrm{pg} / \mathrm{m} l$ and $130.78 \pm 5.18 \mathrm{pg} / \mathrm{ml} ; 0.46 \pm 0.13 \mathrm{ng} / \mathrm{ml}$ and 0.63 $\pm 0.06 \mathrm{ng} / \mathrm{ml} ; 0.32 \pm 0.04 \mathrm{ng} / \mathrm{ml}$ and $0.28 \pm 0.01 \mathrm{ng} / \mathrm{ml}$; $238.22 \pm 35.34 \mathrm{pg} / \mathrm{ml}$ and $216.60 \pm 28.85 \mathrm{pg} / \mathrm{ml}, 0.35 \pm 0.09$ $n \mathrm{~g} / \mathrm{m} l$ and $0.41 \pm 0.08 \mathrm{ng} / \mathrm{ml}$; and $1.18 \pm 0.30 \mathrm{pg} / \mathrm{m} l$ and 2.33 \pm 0.29 , respectively (Table 3 ) and there were no significant difference between Group A and Group B.

\section{DISCUSSION}

The present study clearly demonstrates that an abundant of testosterone was secreted from GTCT in the present cases of mare, and were significantly higher as compared with the levels of normal mares at the breeding and non-breeding seasons. In addition, these high levels were abruptly declined by removal of GTCT. Until now, there are no reports about the source of testosterone in mares with GTCT. It is reported that aromatase play an important role to convert testosterone into estrogen in healthy large follicles [20]. It seems that in the case of GTCT the granulosa cells are unable to expressed aromatase, ultimately testosterone which are produce from the ovary cannot converted into estradiol, consequently the elevated levels of testosterone were observed in the case of GTCT in mares. It was reported that the $\mathrm{GnRH}$ secretion from the pituitary gland are inhibited by negative feedback mechanism of testosterone [5]. Therefore, subnormal levels of other hormones

Table 2. Concentrations of peripheral hormones after removal of GTCT in 6 mares

\begin{tabular}{lcccccc}
\hline Cases & $\begin{array}{c}\mathrm{T} \\
(\mathrm{pg} / \mathrm{m} l)\end{array}$ & $\begin{array}{c}\mathrm{FSH} \\
(\mathrm{ng} / \mathrm{m} l)\end{array}$ & $\begin{array}{c}\mathrm{LH} \\
(\mathrm{ng} / \mathrm{m} l)\end{array}$ & \multicolumn{1}{c}{$\begin{array}{c}\text { ir-INH } \\
(\mathrm{pg} / \mathrm{m} l)\end{array}$} & $\begin{array}{c}\mathrm{P} \\
(\mathrm{g} / \mathrm{m} l)\end{array}$ & \multicolumn{1}{c}{$\begin{array}{c}\mathrm{E}_{2} \\
(\mathrm{pg} / \mathrm{m} l)\end{array}$} \\
\hline Case 1 & $118.91 \pm 15.00$ & $0.40 \pm 0.04$ & $0.23 \pm 0.03$ & $88.60 \pm 22.74$ & $1.33 \pm 0.20$ & $2.18 \pm 0.41$ \\
Case 2 & $131.10 \pm 4.18$ & $0.43 \pm 0.11$ & $0.36 \pm 0.04$ & $191.01 \pm 19.87$ & $1.28 \pm 0.17$ & $4.13 \pm 0.60$ \\
Case 3 & $186.48 \pm 32.43$ & $0.46 \pm 0.13$ & $0.32 \pm 0.04$ & $238.22 \pm 35.34$ & $0.35 \pm 0.09$ & $1.18 \pm 0.30$ \\
Case 4 & $181.16 \pm 81.97$ & $0.53 \pm 0.17$ & $0.32 \pm 0.04$ & $28.62 \pm 62.57$ & $0.16 \pm 0.02$ & $0.82 \pm 0.28$ \\
Case 5 & $253.09 \pm 56.57$ & $0.67 \pm 0.25$ & $0.31 \pm 0.04$ & $232.85 \pm 30.26$ & $0.13 \pm 0.04$ & $0.58 \pm 0.16$ \\
Case 6 & $130.78 \pm 5.18$ & $0.63 \pm 0.06$ & $0.28 \pm 0.01$ & $216.60 \pm 28.85$ & $0.41 \pm 0.08$ & $2.33 \pm 0.29$ \\
\hline Mean \pm SE & $166.92 \pm 20.74$ & $0.52 \pm 0.05$ & $0.30 \pm 0.02$ & $165.98 \pm 35.47$ & $0.61 \pm 0.22$ & $1.87 \pm 0.54$ \\
\hline
\end{tabular}


Table 3. Concentrations of T, FSH, LH, ir-INH, $\mathrm{P}$ and $\mathrm{E}_{2}$ levels in Group A and Group B

\begin{tabular}{ccccccc}
\hline Group & $\mathrm{T}(p \mathrm{~g} / \mathrm{m} l)$ & $\mathrm{FSH}(n \mathrm{~g} / \mathrm{m} l)$ & $\mathrm{LH}(n \mathrm{~g} / \mathrm{m} l)$ & ir- $\mathrm{INH}(p \mathrm{~g} / \mathrm{m} l)$ & $\mathrm{P}(n \mathrm{~g} / \mathrm{m} l)$ & $\mathrm{E} 2(\mathrm{pg} / \mathrm{m} l)$ \\
\hline $\begin{array}{c}\text { A } \\
\begin{array}{c}\text { Case Nos. } \\
(1,2,4 \text { and 5) }\end{array}\end{array}$ & $241.20 \pm 27.98$ & $0.49 \pm 0.13$ & $0.14 \pm 0.01$ & $185.08 \pm 24.91$ & $0.41 \pm 0.10$ & $1.86 \pm 0.61$ \\
\hline B & & & & & & \\
$\begin{array}{c}\text { Case No. 3 } \\
\text { Case No. 6 }\end{array}$ & $186.48 \pm 32.43$ & $0.46 \pm 0.13$ & $0.32 \pm 0.04$ & $238.22 \pm 35.34$ & $0.35 \pm 0.09$ & $1.18 \pm 0.30$ \\
\hline
\end{tabular}

were observed.

It is reported in the mares with GTCT that the contralateral ovary is usually inactive condition $[7,8]$, but regains normal function following surgical removal of the affected ovary. It seems that after removal of the affected ovary the elevated levels of testosterone is declined and consequently FSH and LH can stimulate the contralateral atrophic ovary in inactive condition by the sufficient GnRH secretion, and the contralateral inactive ovary will regain its normal activity. Piquett et al. [20] suggested that the contralateral atrophied ovary will be caused by a lack of FSH stimulation, and GTCT may produce factors that inhibit gonadotropin secretion, although they did not measure the peripheral FSH levels in their mares with GTCT. In the cases with human granulosa cell tumor, it is shown to have contrary correlation between inhibin levels and FSH levels, namely higher levels of inhibin and lower levels of FSH in the peripheral circulation [5]. However, the present study indicates that plasma levels of FSH, LH, inhibin, progesterone and estradiol- $17 \beta$ were lower. It seems that due to the negative feedback of testosterone to GnRH secretions, the lower levels of gonadotropins were observed in this study.

These results suggest that the elevated levels of testosterone were produced from the ovarian follicles in GTCT due to the lack of aromatase. The elevated levels of testosterone may suppress the gonadotropin secretion by negative feedback mechanism, and the high levels of testosterone is a good characteristics for GTCT in mares.

ACKNOWLEDGEMENTS. We are grateful to Dr. Parlow and the National Hormone and Pituitary program (HarborUcla Medica Center, Torrance, CA, U.S.A.) for providing materials for equine FSH and LH RIAs; and Dr. G.D. Niswender (Animal Reproduction and Biotechnology Laboratory, Colarado State University, Fort Collins, Co., U.S.A.) for providing antisera to estradiol-17 $\beta$ (GDN\#244) and progesterone (GDN\#337).

\section{REFERENCES}

1. Baker, C. B. and Kenney, R. M. 1980. Systematic approach to the diagnosis of the infertile or subfertile mare. pp. 721-736. In: Current Therapy in Theriogenology, 2nd ed. (Morrow, D.A. ed.), W.B. Saunders, Philadelphia.

2. Bergeron, H., Crouch, G. M. and Bowen, G. M. 1993. Granulosa theca cell tumor in a mare. Comp. Cont. Educ. Pract. Vet. 5: 141-144.
3. Bergfelt, D. R., Mann, B. G. Schwart, N. B. and Ginther, O. J. 1991. Circulating concentration of ir-INH and FSH during the estrus cycle of mares. Equine Vet. J. 11: 319-322.

4. Bosu, W. T. K., Van Camp, S. C. and Miller, R. G. 1982. Ovarian disorders: Clinical and morphological observation in 30 mares. Can. Vet. J. 23: 6-14.

5. Cogne, C. M., Remeau, J. L. and Hoff, J. 1993. Androgenic granulosa cell tumor of the ovary: in vitro hormonal studies. $J$. Endocrinol. Invest. 16: 545-548.

6. Cordes, D. O. 1969. Equine granulosa tumors. Vet. Rec. 85: 186-188.

7. Daels, P. E. and Hughes, J. P. 1993. The abnormal estrus cycle. pp. 144-160. In: Equine Reproduction (Mckinnen, A. O. and Voss, J. L. eds.), Lea \& Febiger, Philadelphia.

8. Evans, T. J., Constantinescu, G. M. and Ganjam, V. K. 1997. Clinical reproductive anatomy and physiology of the mare. $\mathrm{p}$. 61. In: Current Therapy in Large Animal Theriogenology (Youngquist, R.S. ed.), W.B. Saunders, Philadelphia.

9. Hamada, T., Watanabe, G., Kokuho, T., Taya, K., Sasamoto, S., Hasegawa, Y., Miyamoto, K. and Igarasi, M. 1989. Radioimmunoassay of inhibin in various mammals. J. Endocrinol. 122: 697-704.

10. Hinrichs, K., Elaine, D., Watson, E. D. and Kenney, R. M. 1990. Granulosa cell tumor in a mare with a functional contra lateral ovary. J. Am. Vet. Med. Assoc. 197: 1037-1038.

11. Hoque, M.S., Derar, R.I., Senba, H., Osawa, T., Kano, K., Taya, K. and Miyake, Y-I. 2002. Localization of inhibin $\alpha, \beta$, $\beta \mathrm{B}$ and aromatase in the ovary with Granulosa Theca Cell Tumor (GTCT) in 6 mares. J. Vet. Med. Sci. 65: 713-718.

12. Hughes, J. P., Stabenfeldt, G. H. and Kennedy, P. C. 1980. The estrus cycle and pathological ovarian abnormalities in the mare. Vet. Clin. North. Am. 2: 225-239.

13. Jones, T. C. and Hunt, R. D. 1983. The genital system. pp. 1516-1517. In: Veterinary Pathology. 5th ed. (Jones, T. C. and Hunt eds), Lea \& Febiger, Philadelphia.

14. Jubb, K. V. F., Kennedy, P. C. and Palmer, N. 1985. The female genital system. pp. 502-507. In: Pathology of Domestic Animals. 3rd ed. (Jubb, K. V. F., Kennedy, P. C. and Palmer, N. eds.), Academic Press, New York.

15. Lappohn, R. E., Burger, H., Bouma, J., Bangah, M., Krans, M. and Debruijin, H. W. A. 1989. Inhibin as a marker for granulosa cell tumors. New Engl. J. Med. 321: 790-793.

16. Liu, I. K. M. 1987. Ovarian abnormalities. pp. 500-503. In: Current Therapy in Equine Medicine, 2nd ed. (Robinson, N. E. ed.), W.B. Saunders, Philadelphia.

17. McKinnen, A. O., Voss, J. L., Squires, E. L. and Carnevale, E. M. 1993. Diagnostic ultrasonography. pp. 266-302. In: Equine Reproduction, (McKinnen, A. O. and Voss, J. L. eds.), Lea and Febiger, Philadelphia.

18. Meghar, D. M., Wheat, J. D., Hughes, J. P., Stabenfeldt, G. H. and Harris, B. A. 1977. Granulosa cell tumors in mares a 
review of 78 cases. Proc. Am. Equine Pract. 23: 133-143.

19. Meinecke, B. and Grips, H. 1987. Steroid hormone secretory patterns in a mares with granulosa cell tumors. J. Vet. Med. Assoc. 34: 545-560.

20. Nagamine, N., Nambo, Y., Nagata,S., Nagoka, K., Tsunoda, N., Taniyama, H., Tanaka, Y., Tohei, A., Watanabe, G. and Taya, K. 1998. Inhibin secretion in the mare: Localization of inhibin $\alpha, \beta \mathrm{A}$, and $\beta \mathrm{B}$ subunits in the ovary. Biol. Reprod. 59: 1392 1398.

21. Noris, H. J., Taylor, H. B. and Garner, F. M. 1998. Equine ovarian granulosa tumors. Vet. Rec. 82: 419-420.

22. Piquette, G. N., Kenney, R. M., Sertich, P. A., Yamato, M. and Hsueh, J. W. 1990. Equine granulosa theca cell tumors express inhibin $\alpha$ and $\beta$ A subunit messenger ribonucleic acids and proteins. Biol. Reprod. 43: 1050-1057.

23. Schwall, R. H., Mason, A. J., Wlcox, J. N., Bassett, S. G. and
Zeleznix, A. J. 1990. Localization of inhibin/Activin subunit mRNAs with in the primate ovary. Mol. Endocrinol. 4: 75-79.

24. Stabenfeldt, G. H., Hughes, J. P., Kennedy, P. C., Meghar, D. M. and Neely, D. P. 1997. Clinical findings, pathological changes, and endocrinological secretory patterns in mares with ovarian tumors. J. Reprod. Fertil. 27: 277-285.

25. Stickle, R. L., Erb, R. E., Fessler, J. F. and Runnels, L. J. 1975. Equine granulosa cell tumors. J. Am. Vet. Med. Assoc. 167: $148-151$.

26. Taya, K. and Sasamoto, S. 1988. Selective release of FSH in lactating rats during the period of follicular atresia induced by administration of antiserum to LH releasing hormone. J. Endocrinol. 118: 455-464.

27. White, R. A. S. and Allen, W. R. 1985. Use of ultrasound echography for the differential diagnosis of a granulose cell tumor in a mare. Equine Vet. J. 17: 401-402. 